\title{
Artykuty
}

Klio. Czasopismo poświęcone dziejom Polski i powszechnym

PL ISSN 1643-8191, t. 50 (3)/2019, s. 43-64

(c) (1) $\Theta$

http://dx.doi.org/10.12775/KLIO.2019.036

BARTOSZ STARĘGOWSKI"

\section{Samorząd szlachecki województu poznańskiego i kaliskiego wobec cudzoziemskich żołnierzy i oficerów w wojsku powiatouym podczas panowania Jana Kazimierza (1648-1668)}

\author{
The nobility self-government of the Poznań and Kalisz \\ voivodships towards foreign soldiers and officers \\ in the county troops during the reign of Jan Kazimierz \\ (1648-1668)
}

Streszczenie: Wojsko powiatowe, jako siła zbrojna samorządu, było w całości organizowane przez sejmiki. To one decydowały, jakiego rodzaju formacje i oficerowie wchodzili w jego skład. Sejmik obu województw, poznańskiego i kaliskiego, często stawał przed problemem powoływania wojska autoramentu cudzoziemskiego i narodowego. Wielkopolska graniczyła przecież z Brandenburgią i Śląskiem, będąc pod silnym wpływem trendów

* Uniwersytet Marii Curie-Skłodowskiej w Lublinie, pl. M. Curie-Skłodowskiej 5, 20-031 Lublin, mroczek509@vp.pl, ORCID: 0000-0002-4775-0162. 
zachodnioeuropejskich. Z drugiej jednak strony tamtejsza szlachta odnosiła się nieprzychylnie do służby cudzoziemców w armii koronnej, co zresztą było wówczas typowe dla przedstawicieli całego stanu Rzeczypospolitej. Problem ten nasilił się w okresie powstania Chmielnickiego. Po śmierci Władysława IV, w uniwersałach interreksa, pojawiło się zalecenie zaciągania formacji cudzoziemskich, szczególnie tych dysponujących dużą siłą ognia. Powszechnie miano nadzieję, że wobec porażek armii koronnej Wielkopolska sięgnie po weteranów wojny trzydziestoletniej, zaciagając chorągwie powiatowe, które miały zostać posłane na Ukrainę. Celem tematu podjętego w artykule jest ukazanie postawy Wielkopolan wobec żołnierzy i oficerów zaciągu cudzoziemskiego, problemów, jakie występowały w wojskach tego typu, ustosunkowania się do presji wywieranej przez władze centralne oraz alternatywnych propozycji szlachty wielkopolskiej dotyczących służby „obcych" w wojskach samorządowych.

Abstract: County troops, as the armed force of self-government, was entirely organized by province assemblies. They decided which types of formations and officers were included in its composition. Province assembly of poznański and kaliski voivodeships, often faced the problem of establishing the army of foreign and national recruitments. Greater Poland bordered with Brandenburg and Silesia, being strongly influenced by Western European trends. On the other hand, the nobility there was unfavorably serving the foreigners in the Crown Army, which was typical for representatives of the entire state of the Commonwealth at the time. This problem intensified during the Chmielnicki uprising. After the death of Vladislav IV, in the interreks universals, a recommendation was made to enlist foreign formations, especially those with a large firepower. It was commonly believed that in the face of the defeats of the crown army, Greater Poland would reach for the veterans of the Thirty Years' War by recruiting county troops that were to be sent to Ukraine. The aim of the subject taken in the article is to show the attitude of the inhabitants of Greater Poland against foreign recruitment soldiers and officers, problems that occurred in this type of army, respond to the pressure exerted by the central authorities and alternative proposals of the Greater Poland gentry regarding the service of "foreigners" in the army of local government.

Słowa kluczowe: wojsko powiatowe, dragonia, arkebuzeria, sejmik, piechota, Rozdrażewski

Keywords: county troops, dragoon's, arequebuse raiders, Provence assembly, infantry, Rozdrażewski 
Reczpospolita Obojga Narodów, jako państwo w zakresie tworzenia Wwłasnej siły zbrojnej, często korzystała z usług żołnierzy i oficerów zagranicznego pochodzenia. Uzupełniano w ten sposób braki w armii państwowej, choćby w przypadku zapotrzebowania na artylerię, piechotę czy wsparcie tzw. ludu ognistego ${ }^{1}$. Przez długi czas jednostki cudzoziemskie służyły głównie jako wojska najemne, za których usługi płacono całkiem niemałe pieniądze 2 . Już za czasów Zygmunta III na szerszą skalę pojawiali się w armii koronnej oficerowie mający cudzoziemskie pochodzenie. Zjawisko to było wszak zgodne z polityką tego monarchy, który wprost ingerował w działalność wielu instytucji państwowych, obsadzając w nich oddanych sobie cudzoziemców ${ }^{3}$. Co jednak najistotniejsze, oficerowie zagraniczni posiadający zarówno wiedzę praktyczną, zdobytą w trakcie licznych wojen toczonych w zachodniej Europie, jak i teoretyczną nabytą na zachodnich uniwersytetach byli niezwykle przydatni dla armii koronnej czy litewskiej. Do czasu wykształcenia rodzimych kadr oficerskich korzystano właśnie z ich wiedzy dotyczącej inżynierii wojskowej, artylerii czy optymalnego wykorzystania piechoty na polu bitewnym.

O cudzoziemskiej kadrze oficerskiej i jej procentowym udziale wśród oficerów armii koronnej napisano kilka opracowań. Sztandarowa praca, poświęcona całemu korpusowi oficerskiemu, wyszła spod pióra Marka Wagnera, który dokonał analizy całej kadry oficerskiej w drugiej połowie XVII wieku, badając przy tym udział cudzoziemców w jej strukturach. $\mathrm{Na}$ podstawietych badań Marek Wagner napisał także artykuł dotyczący podoficerów w armii koronnej ${ }^{4}$, oficerów pochodzenia szkockiego w armii

1 „Ludem ognistym” nazywano najczęściej formacje dysponujące dużą siłą ognia jak rajtarzy, dragonii oraz piechota i arkebuzeria.

2 J. Wimmer, Wojsko polskie w drugiej potowie XVII w., Oświęcim 2013, s. 33-34.

3 P. Gawron, Proces tworzenia kadry oficerskiej armii koronnej w czasach Zygmunta III Wazy (1587-1632), [w:] Organizacja armii w nowożytnej Europie. Struktura-urzędy-prawo-finanse, Zabrze 2011, s. 244, 250, 263-273. Szczególną uwagę Zygmunt III poświęcał piechocie, dragonii i rajtarii w zakresie wyznaczania dla nich oficerów.

4 M. Wagner, Korpus oficerski wojska polskiego w drugiej potowie XVII wieku, Oświęcim 2015; idem, Podoficerowie armii koronnej w drugiej potowie XVII w., „Studia i Materiały do Historii Wojskowości” (dalej SMHW) 1992, t. 34, s. 67-99. 
polskiej ${ }^{5}$ i formacji dragońskich w armii Jana III' ${ }^{6}$ Kadrę oficerską pod kątem prozopograficznym przeanalizował także Karol Kościelniak, jednak jego badania obejmują okres od 1576 do 1648 roku$^{7}$. Kwestie związane z zagranicznym pochodzeniem oficerów poruszał też Zbigniew Hundert na łamach swojej pracy dotyczącej udziału wojska koronnego w walce stronnictw politycznych w latach 1669-1673 . Na kartach swoich artykułów zagadnienie to podjął również kilkukrotnie Mirosław Nagielski, dokonując charakterystyki gwardii królewskiej’ ${ }^{9}$ Kwestie związane z kadrą oficerską, aczkolwiek tylko na podstawie dragonii, przedstawił również Zbigniew Kuchowicz $^{10}$. Jak możemy zauważyć, w większości przytoczone opracowania i artykuły dotyczyły armii państwowej. Wojsko samorządowe nie doczekało się tak dokładnych badań pod tym względem. Próbę charakterystyki dotyczącej wojska samorządowego, a ściślej rzecz ujmując wojsk powiatowych z terenu Małopolski i Rusi Czerwonej, podjął Dariusz Kupisz. Z punktu widzenia tematyki rozważań podjętych w artykule niezwykle istotny jest rozdział czwarty, w którym autor poświęca uwagę np. pochodzeniu etnicznemu i terytorialnemu oficerów oraz żołnierzom służącym w tego

5 Idem, Szkoccy oficerowie wojska polskiego w drugiej potowie XVII wieku, [w:] Od armii komputowej do narodowej. Problemy organizacyjne sit zbrojnych od XVI do XX wieku, t. 3, red. J. Centek, M. Krotofil, Toruń 2009.

${ }^{6}$ Idem, Formacje dragońskie $w$ armii koronnej $w$ czasach Jana III Sobieskiego, [w:] Do szarży marsz, marsz... Studia z dziejów kawalerii, red. A Smoliński, t. 5, Toruń 2014.

7 K. Kościelniak, Kadra oficerska w wojsku koronnym $w$ latach 1576-1648. Studia nad zawodem wojskowym, Toruń 2011.

8 Z. Hundert, Między butawa a tronem. Wojsko koronne $w$ walce stronnictwa malkontentów z ugrupowaniem dworskim w latach 1669-1673, Oświęcim 2014.

9 M. Nagielski, Opinia szlachecka o gwardii królewskiej w latach 1632-1668, „Kwartalnik Historyczny” (dalej KH) 1985, t. 32, z. 3, s. 549-576; idem, Gwardia królewska szkota. korpusu oficerskiego autoramentu cudzoziemskiego Rzeczpospolitej za dwóch ostatnich Wazów (1632-1668), „Przegląd Historyczny” (dalej PH) 1982, t. 73, z. 3-4, s. 207-225; idem, Spoteczny i narodowy sktad gwardii królewskiej za dwóch ostatnich Wazów (1632-1668), SMHW 1988, t. 30, s. 61-102.

10 Z. Kuchowicz, Udziat dragonii w walce z najazdem szwedzkim w latach 1655-1660, SMHW 1956, t. 2, s. 289-299. 
typu formacji zbrojnej ${ }^{11}$. Oprócz wyżej wspomnianej monografii zagadnienie wojska powiatowego pojawiało się jeszcze kilkukrotnie w mniejszych tekstach, zarówno D. Kupisza, jak i innych autorów ${ }^{12}$. Natomiast tematyka wojsk powiatowych pochodzących stricte z terytorium województw poznańskiego i kaliskiego z okresu panowania Jana Kazimierza Wazy pojawiła się dopiero w artykule Jolanty Dworzaczkowej ${ }^{13}$. Jest to dość krótki tekst, pomijający wiele kwestii związanych z wojskiem samorządowym w Wielkopolsce, niemniej jednak będący solidnym przyczynkiem do badań w tym

11 D. Kupisz, Wojska powiatowe samorząów Matopolski i Rusi Czerwonej, Lublin 2008, s. 179-218.

12 Idem, Wojsko powiatowe jako samoobrona terytorialna województwa sandomierskiego w XVII i na początku XVIII wieku, „Między Wisłą a Pilicą. Studia i Materiały Historyczne” 2006, t. 7; idem, Choragwie powiatowe ziemi chetmskiej w XVI-XVII wieku, „Rocznik Chełmski” 2006, t. 10; idem, Choragwie powiatowe województw matopolskich jako formacje samoobrony terytorialnej w pierwszej potowie XVII wieku, SMHW 2006, t. 42; idem, Wojsko powiatowe województwa wotyńskiego w XVII wieku, „Naukovyj Visnik Volynskoko Nacjonalnogo Universytetaim. Lesi Ukrainki” 2009, t. 22; idem, Projekt organizacji obrony terytorialnej księcia Krzysztofa Zbaraskiego z 1624 r. i jego realizacja przez samorząd szlachecki województw matopolskich, [w:] Nad spoteczeństwem staropolskim, red. D. Wereda, t. 2, Akademia Podlaska, Siedlce 2009; idem, Ochrona pogranicza przez sity zbrojne samorzadu województwa ruskiego w drugiej potowie XVII wieku, [w:] Urzędy państwowe, organy samorządowe i kościelne oraz ich kancelarie na polsko-ruskim pograniczu kulturowym i etnicznym od XV do XIX wieku, red. H. Gmiterek, J. Łosowski, Kraków 2010; idem, Próby organizacji wojsk „obrony domowej” przez szlachtę województw kijowskiego, bractawskiego i czernichowskiego (1649-1650), KH 2018, t. 125, z. 1; A. Borowiak, Wojska powiatowe przed kampania pitawiecka w 1648 r., [w:] Studia nad staropolska sztuka wojenna, t. 2, red. Z. Hundert, Oświęcim 2013; Z. Hundert, Wojska zaciagnięte przez samorząd lokalny ziemi warszawskiej w latach 1671-1673, „Almanach Warszawy” 2015, t. 9; idem, Zaciężne wojsko powiatowe sejmiku wiszeńskiego województwa ruskiego $w$ latach 1671-1673 oraz jego rola $w$ dziataniach wojskowych i politycznych Jana Sobieskiego, PH 2017, t. 108, z. 4; idem, Powiatowe choragwie kozackie (pancerne) województw poznańskiego i kaliskiego w latach 1671-1673, [w:] Do szarży marsz, marsz... Studia z dziejów kawalerii, red. A. Smoliński, t. 6, Toruń 2015; B. Staręgowski, W stużbie województwom wielkopolskim i Rzeczypospolitej. Okoliczności sformowania i dziatalność putku Bogustawa Leszczyńskiego w latach 1648-1649, „Res Historica" 2017, t. 44; M. Zwierzykowski, Geneza i funkcjonowanie choragwi policyjnej województw poznańskiego i kaliskiego w latach 1734-1767, [w:] W podróży przez wiek osiemnasty..., red. A. Perłakowski, M. Wyszomirska, M. Zwierzykowski, Kraków 2015.

13 J. Dworzaczkowa, Sprawy wojska na sejmikach wielkopolskich w latach 1648-1661, [w:] Pax et Bellum, red. K. Olejnik, Poznań 1993, s. 55-64. 
zakresie. Ponadto autorka przedstawia również swoje spostrzeżenia odnośnie do udziału cudzoziemców w ramach struktur wojsk wystawianych przez sejmik. Na początek kilka istotnych uwag tytułem wprowadzenia.

\section{Procesy kształtowania się wojska samorządowego a zaciąg cudzoziemski}

Przykładowo, pomysł zwiększenia zaangażowania wojsk cudzoziemskich $\mathrm{w}$ ramach armii koronnej pojawił się na listopadowym sejmie w 1620 roku, zaraz po klęsce hetmana wielkiego koronnego Stanisława Źółkiewskiego pod Cecorą. Wśród niektórych senatorów, szczególnie w stanowisku podskarbiego wielkiego koronnego Mikołaj Daniłowicza, pobrzmiewał postulat o zwiększeniu udziału wojsk obcych w strukturze armii, przeciwstawiając je niewydolnemu i nieskutecznemu pospolitemu ruszeniu ${ }^{14}$. Z kolei w izbie poselskiej książęta Krzysztof i Jerzy Zbarascy również wspominali o wykorzystaniu żołnierzy zagranicznych, w szczególności piechoty i artylerii z Francji, tudzież z Holandii. Były to jednak tylko projekty parlamentarne $^{15}$. Dopiero wyodrębnienie się zaciągu niemieckiego w armii polsko-litewskiej, wymuszone niejako jej niepowodzeniami w walce ze Szwecją, normowało w pewien sposób formy zaciągania formacji mających charakter nienarodowy ${ }^{16}$.

Specyfika wojska powiatowego polegała na tym, że najważniejsze aspekty jego funkcjonowania regulował sejmik szlachecki, a nie organy centralne państwa polskiego. To od jego decyzji zawartych w laudach sejmikowych zależał charakter zaciagganej formacji, kadra oficerska czy wysokość wypłacanego żołdu ${ }^{17}$. Sejmik średzki, wspólny dla województw kaliskiego i poznańskiego, był jednym z najważniejszych w całej Rzeczypospolitej.

14 J. Pietrzak, Po Cecorze i podczas wojny chocimskiej: sejmy z lat 1620-1621, Wrocław 1983, s. 52-58.

15 Ibidem, s. 62.

16 K. Olejnik, Dzieje oręża polskiego, Toruń 2004, s. 64-65; J. Teodorczyk, Wojskowość polska w pierwszej potowie XVII w., [w:] Historia wojskowości polskiej. Wybrane zagadnienia, red. W. Biegański, P. Stawecki, J. Wojtasik, Warszawa 1972, s. 190-191.

17 D. Kupisz, Wojska powiatowe..., s. 131-134, 177-178. 
Wiele mniejszych sejmików całej prowincji wielkopolskiej było pod jego przemożnym wpływem politycznym ${ }^{18}$. Kolejnym niezwykle ważnym aspektem były zachodnioeuropejskie prądy kulturowe docierające do Wielkopolski poprzez granicę z marchią brandenburską i Śląskiem. Napływ tychże wzorców na pewno w znaczący sposób odbił się na charakterze wojsk wystawianych przez sejmik. Ponadto Wielkopolska była nadzwyczaj zamożną prowincją ${ }^{19}$, zatem mogła sobie pozwolić na werbunek nawet najdroższych formacji. Niemniej jednak sytuacja wyglądała na dość skomplikowaną. Wielkopolanie bardzo niechętnie korzystali z usług cudzoziemskich żołnierzy i oficerów. Należałoby doszukiwać się powodów tego stanu rzeczy przede wszystkim w kwestiach finansowych oraz braku zaufania do oficerów cudzoziemskich $\mathrm{w}$ odniesieniu do spraw związanych choćby $\mathrm{z}$ dyscypliną żołnierską.

W pierwszej połowie XVII wieku na powołanie żołnierzy cudzoziemskich w ramach wojska powiatowego szlachta wielkopolska zdecydowała się tylko trzy razy: w 1635, 1640 i 1646 roku, zatem dopiero po reformach Władysława IV. W składzie wojsk sejmiku średzkiego pojawiła się wówczas rajtaria i piechota cudzoziemskiego autoramentu. Laudum z kwietnia 1635 roku powoływało regiment rajtarski pod dowództwem Przecława Leszczyńskiego i dwa pułki piechoty z Eliaszem Arciszewskim i Krzysztofem Przyjemskim na czele ${ }^{20}$. Drugie z marca 1640 roku na planowaną wojnę z Turcją formowało oddziały w sile 1200 żołnierzy, wśród których 400 stanowiły dwa regimenty piechoty cudzoziemskiej pod komendą Stefana Dembińskiego i Krzysztofa Szczodrowskiego ${ }^{21}$. Trzecie z września

18 M. Zwierzykowski, Samorząd sejmikowy województw poznańskiego i kaliskiego w latach 1696-1732, Poznań 2010, s. 23; idem, Komisja Skarbowa Poznańska. Z dziejów sejmikowej administracji i sadownictwa skarbowego w Wielkopolsce w XVII i XVIII wieku, Poznań 2003, s. 17-18.

19 J. Topolski, Wzrost gospodarczy $i$ jego bariery. Aktywizacja ekonomiczna szlachty, [w:] Dzieje Wielkopolski, red. J. Topolski, t. 1, Poznań 1969, s. 443-444, 476-477, 479-480; idem, Wielkopolska poprzez wieki, Poznań 1999, s. 94-98, 118.

20 Laudum sejmiku województw poznańskiego i kaliskiego, Środa 30 IV 1635, Biblioteka XX. Czartoryskich w Krakowie (dalej BC), sygn. 1774, s. 154-157.

21 Laudum sejmiku województw poznańskiego i kaliskiego, Środa 27 III 1640, BC, 137, s. 273-274. 
1646 roku powoływało głównie piechotę cudzoziemską pod osobistą komendą starosty generalnego Bogusława Leszczyńskiego i weterana Jacka Rozdrażewskiego ${ }^{22}$. Jak widzimy w powyższych przypadkach, formacje mające charakter cudzoziemski dowodzone były przez Polaków, a ściślej rzecz biorąc - rodowitych Wielkopolan. Samym formacjom nie dane było brać udziału w walkach, ponieważ w wyniku konsekwencji wydarzeń natury politycznej ${ }^{23}$ żaden z zaciągów nie miał możliwości sprawdzenia swojej gotowości bojowej i pozostał jedynie jako treść laud wpisanych do ksiąg grodzkich. Województwa decydowały się bardzo często na zaciąganie arkebuzerii, będącej swoistym substytutem wojsk cudzoziemskich. Z jednej strony miała ona pewne elementy charakteru zachodnioeuropejskiego i w takim walczyła stylu, z drugiej jednak była werbowana poprzez zaciąg towarzyski, dzięki czemu zachowała również cechy polskiego systemu wojskowego ${ }^{24}$. Oczywiście na czele własnych wojsk sejmik starał się osadzać przedstawicieli rodzin wielkopolskich, a sam zaciąg najczęściej dokonywany był wśród mieszkańców obu województw. Na tym tle dojdzie w okresie panowania Jana Kazimierza do ostrych sporów pomiędzy sejmikiem a władzami centralnymi.

\section{Zaciąg cudzoziemski w ramach wojska powiatowego województu poznańskiego i kaliskiego w okresie panowania Jana Kazimierza 1648-1668}

$\mathrm{Na}$ krótko przed śmiercią Władysława IV wybuchło największe powstanie kozackie na Ukrainie pod wodzą pisarza zaporoskiego Bohdana

22 Laudum sejmiku województw poznańskiego i kaliskiego, Środa 13 IX 1646, BC, 1774, s. 192-196; M. Nagielski, Rozdrażewski Jacek, [w:] „Polski Słownik Biograficzny” (dalej PSB) 1989-1991, t. 32, s. 366.

23 Krzysztof Opaliński do brata Łukasza, Tuliszków XII 1646, [w:] Listy Krzysztofa Opalińskiego do brata Eukasza 1641-1653, red. R. Pollak, Wrocław 1957, s. 368; D. Kupisz, Wojska powiatowe..., s. 243; T. Nowak, J. Wimmer, Historia oręża polskiego 963-1795, Warszawa 1981, s. 433-434.

24 M. Nagielski, Organizacja rajtarii i arkebuzerii koronnej w XVII w., [w:] Organizacja armii..., s. 197-199. 
Chmielnickiego. Na przestrzeni lat do walki w tym regionie kraju zmobilizowano ogromne siły, których integralną częścią składową były również wojska województw wielkopolskich. Z całego okresu panowania Jana Kazimierza w czasie walk z Kozakami sejmik średzki zaciągnął najwięcej wojsk powiatowych. Jeszcze w okresie bezkrólewia prymas Maciej Łubieński w swoim uniwersale apelował do sejmików, by zaciągały wojska do obrony ojczyzny, ale z zastrzeżeniem, aby „Nie kozaków tedy ale ognistego/żelaznego/potężnego wojska potrzeba to jest usarzów, rajtarów, draganów y piechoty niemieckiej, [...] nie ufając zaciągom chłopstwa naszego, ale raczej wszystkie nadzieje w samej nas szlachcie i w ludziach cudzoziemskich [...]"25. Zjazd w Poznaniu 8 czerwca postanowił zadość uczynić tej prośbie. Województwa poznańskie i kaliskie wystawiły cztery pułki, posiłkowane dodatkowo suplementami prywatnymi. Składały się przede wszystkim z husarii i arkebuzerii. Tylko jeden pułk pod dowództwem Jacka Rozdrażewskiegow całościstanowili dragoni ${ }^{26}$. Niestety, o jego składzie i organizacji w tym konkretnym momencie wiemy bardzo niewiele. Jedyny kapitan, którego udało się ustalić, to Nataniel Lipka ${ }^{27}$. Zjazd w Poznaniu nie regulował, jakich oficerów mieli zaciągnąć pułkownicy, a pozostawił to w gestii samych dowódców. Natomiast w kwestii żołnierzy mieli być to mieszkańcy Wielkopolski ${ }^{28}$.

$\mathrm{Na}$ popisach wspomnianych zgrupowań pojawiły się również prywatne suplementy, w postaci choćby dragonii i piechoty zaciągu cudzoziemskiego, ale na ich czele stali Wielkopolanie, a sami żołnierze zgodnie z wolą sejmiku wywodzili się z mieszkańców obu województw. Jedynie chorągiew dragońska Aleksandra Kostki miała składać się z „[...] Finów, Semigalczyków i Niemców [...]"29. Tak zorganizowane wojska powiatowe dotarły pod

25 Uniwersał Macieja Łubieńskiego do szlachty województw poznańskiego i kaliskiego, Warszawa 26 V 1648, Archiwum Państwowe w Poznaniu (dalej APPoz.), Księgi grodzkie poznańskie (dalej Gr. Pozn.), sygn. 693, k. 484-485v.

26 Laudum zgromadzenia województw poznańskiego i kaliskiego, Poznań 8 VI 1648, BC, 1774, s. 202-212.

27 Protestacja kapituły poznańskiej, APPoz., Gr. Pozn., 694, k. 218-218v.

28 „...JMP Starosta rotmistrzów także sobie szlachtę dobrze osiadłą przybierać ma...” Zob. Laudum poznańskie, Poznań 8 VI 1648, BC, 1774, s. 203.

29 Popis pułku Andrzeja Grudzińskiego, Gniezno 27 VII 1648, Popis pułku Jakuba Rozdrażewskiego, Kalisz 28 VII 1648, APPoz., Gr. Pozn., 693, k. 625v-630, 683v-688. 
Piławce $^{30}$. Jednak w obliczu niekorzystnego dla strony polskiej przebiegu wydarzeń wojska rozpadły się, a problem ich organizacji poruszono na sejmie $\mathrm{w}$ październiku ${ }^{31}$. Zdecydowano wówczas o utrzymaniu uchwalonej uprzednio przez sejmik liczby żołnierzy (2200), ale sejmik średzki z grudnia postanowił o zmianie organizacji. Utrzymano pułk Jacka Rozdrażewskiego $^{32}$, powołano natomiast dodatkowy pułk piechoty autoramentu cudzoziemskiego pod komendą Stanisława Latalskiego ${ }^{33}$, w dowództwie którego pojawił się Niemiec, kapitan Zenoman ${ }^{34}$. W trakcie służby nie dochodziło do jakichś szczególnych nadużyć, aczkolwiek w rejestrze szkód dokonanych w województwie kaliskim pojawia się wzmianka o pułku Jacka Rozdrażewskiego i prywatnej choragwi dragońskiej jego kuzyna, kasztelana kaliskiego Jakuba Rozdrażewskiego, które dokonały grabieży w Lubomierzu i Pawłówku ${ }^{35}$. Szczególne zasługi w tym procederze położył Nataniel Lipka, który dokonał najazdu na kilka wsi, a w szczególności dał się we znaki w miasteczku Buk, gdzie dragoni Lipki o mało nie dopuścili się morderstwa na miejscowym burmistrzu ${ }^{36}$. $\mathrm{Na}$ razie jednak nie obwiniano za te ekscesy tylko wojsk cudzoziemskich, gdyż dokonywała ich większość chorągwi powiatowych, przez co oskarżenia padały na wszystkich żołnierzy, a nie tylko tych z formacji cudzoziemskich ${ }^{37}$. Poza tym na czele zgrupowań stali Polacy,

30 J. Dworzaczkowa, Sprawy wojska..., s. 57.

31 A. Radziwiłl, Pamiętnik o dziejach w Polsce, t. 3 (1647-1656), oprac. A. Przyboś, R. Żelewski, Warszawa 1980, s. 130; Volumina Constitutionum (dalej VC), t. 4 (1641-1668), vol. 1 (1641-1658), red. S. Grodziski, M. Kwiecień, K. Fokt, Warszawa 2015, s. $156-157$.

32 Zwiększono go jednak do 550 dragonów.

33 Laudum sejmiku województw poznańskiego i kaliskiego, Środa 17 XII 1648, APPoz., Gr. Pozn., 693, k. 801-803v, B. Czart., 1774, s. 215-217.

34 Lustracja wojskowa pułku Stanisława Latalskiego, Krzemieniec 20 III 1649, APPoz., Gr. Pozn., 694, k. 455-455v.

35 Rejestr szkód w województwie kaliskim, dokonanych przez żołnierzy w służbie Rzeczypospolitej, APPoz., Księgi grodzkie kaliskie (dalej Gr. Kal.), sygn. 274, k. 96v-107.

36 Zob.Protestacja kapituły poznańskiej, APPoz., Gr. Pozn., 694, k. 218-218v.

37 Szkody w Liskowie i Zychowie - Andrzej Skórzewski, Stanisław Skrzetuski i Marcin Krzywański, w Kochanowie i Pawłodzku - Piotr Tomicki, w Lubomierzu i w Pawłówku - pułk Jacka Rozdrażewskiego i prywatny regiment dragoński Jakuba Rozdrażewskiego pod dowództwem kapitana Jerzego Przybylskiego. Zob. Rejestr szkód w województwie 
co samo w sobie miało znaczenie niwelujące negatywne odczucia lokalnej społeczności. Nastroje poprawiały również doniesienia o sukcesach w walce. Wypada wspomnieć również o tym, że niezależnie od sejmiku niektóre chorągwie zmieniły swój charakter. Laudum przewidywało powołanie chorągwi złożonych w całości z arkebuzerów, z wyjątkiem wspomnianych pułków Rozdrażewskiego i Latalskiego. Jednakże dwie chorąwie Wojciecha Albrechta Smoguleckiego i Krzysztofa Unrugapo dotarciu do Zbaraża wyglądały inaczej, niż przewidywało laudum. Unrug przyprowadził rajtarów, a Smogulecki dragonów ${ }^{38}$. Natomiast sam pułk Rozdrażewskiego nad wyraz dobrze sprawował się pod Zbarażem, pomijając fakt zdrady kilku dragonów, którzy zniweczyli plan jednego z ataków na pozycje kozackie ${ }^{39}$. W dowództwie nowego pułku po reorganizacji laudum z 17 grudnia znalazło się czterech Niemców: podpułkownik Andrzej Reizer i kapitanowie Jakub Lemka, Jakub Bodke i Salomon Kindler ${ }^{40}$. W trakcie walk Rozdrażewski został ranny, co uniemożliwiło mu powrót do Wielkopolski razem ze swoimi żołnierzami. Jak się okazało, miało to bardzo negatywne skutki. Jeden z rotmistrzów powiatowych, Mikołaj Szczęsny Pogórski, informował sejmik o tym, że pozbawieni dowództwa Rozdrażewskiego dragoni

kaliskim, dokonany przez żołnierzy w służbie Rzeczypospolitej, APPoz., Gr. Kal., 274, k. 96v-107.

38 Asygnacja skarbowa dla chorąwi Krzysztofa Unruga, Asygnacja skarbowa dla choraggwi Wojciecha Albrechta Smoguleckiego, APPoz., Komisja Skarbowa Poznańska (dalej KSP), sygn. 1, k. 18-19v.

39 Akta Anni 1649 pod Zbarażem Nowym albo raczej diariusz $w$ miesiacu lipcu za regimentu jm. pana Andrzeja z Dambrowice Firleja kasztelana natenczas betskiego, jm pana Stanistawa z Brzezia Lanckorońskiego kasztelana kamienieckiego, jm. pana Mikotaja Ostroroga podczaszego koronnego, [w:] Relacje wojenne z pierwszych lat walk polsko-kozackich powstania Bohdana Chmielnickiego okrsu „Ogniem i Mieczem”(1648-1651), oprac. M. Nagielski, Warszawa 1999, s. 158; Dyariusz obszerny oblężenia Zbaraża, [w:] J. Michałowski, Jakuba Michatowskiego, wojskiego lubelskiego, a później kasztelana bieckiego. Księga Pamiętnicza, wyd. A.Z. Helcel, Kraków 1864, s. 466; M. Nagielski, Rozdrażewski Jacek..., s. 367; K. Śledziński, Zbaraż 1649, Warszawa 2005, s. 117-118.

40 Asygnacja skarbowa dla regimentu kapitana Jakuba Lemka, Asygnacja skarbowa dla regimentu kapitana Jakuba Bodke, Asygnacja skarbowa dla regimentu kapitana Salomona Kindlera, Asygnacja skarbowa dla regimentu pułkownika Jacka Rozdrażewskiego, Asygnacja skarbowa dla regimentu podpułkownika Andrzeja Reizera, APPoz., KSP, 1, k. 26-28, $29 \mathrm{v}, 31 \mathrm{v}, 36 \mathrm{v}$. 
zaatakowali miasteczko Waliszew i sterroryzowali jego mieszkańców ${ }^{41}$. Tymi sprawami oraz wieloma innymi miała zająć się specjalna komisja powołana przez sejmik.

Komisja Skarbowa Poznańska rozpoczęła pracę 31 stycznia 1650 roku, a skończyła z początkiem jesieni tegoż roku. Jej celem było należyte przeliczenie choragwi i wypłacenie żołdu oraz rozpatrzenie spraw związanych $\mathrm{z}$ nadużyciami konkretnych chorągwi ${ }^{42}$. Z rejestru spraw sporządzonych na komisji jasno wynika, że spraw o nadużycia pułku Rozdrażewskiego było zaledwie kilka z kilkuset zawartych w rejestrze. Najwięcej skarg było na rotmistrzów Andrzeja Skórzewskiego i Piotra Tomickiego ${ }^{43}$.

Ostatecznie jednak, w obliczu konieczności związanej z nasileniem walk, sejmik po raz kolejny zdecydował się na powołanie pułku pod dowództwem Rozdrażewskiego, tym razem złożonego z 600 porcji piechoty ${ }^{44}$. $\mathrm{Na}$ jego czele stanęło trzech Niemców, nieznani z imienia Szaltz i kapitan lejtnant Flaun oraz po raz kolejny jako podpułkownik Andrzej Reizer. Drugą część ogniwa dowódczego stanowili kapitanowie polskiego pochodzenia Morawiec i Bojanowski oraz osławiony Nataniel Lipka ${ }^{45}$. Stało to nieco w sprzeczności z zaleceniami sejmiku, który wprost mówił o tym, by „[... piechoty dobrze ćwiczonej z kapitanami dobrymi możnali szlachcicami polskimi opatrzonych wystawić na tę usługę Rzplitej powinien będzie [...]"46. W obliczu nasilenia działań zbrojnych w niedługim czasie na szczeblu centralnym podjęto decyzję o powiększeniu pułku Rozdrażewskiego do 1200 porcji oraz włączeniu go jako wojska suplementowego do służby państwowej $^{47}$. W tym samym czasie pułkownik arkebuzerów wielkopolskich,

41 Protestacja Mikołaja Pogórskiego, APPoz., Gr. Pozn., 695, k. 291v-292v.

42 M. Zwierzykowski, Komisja Skarbowa Poznańska..., s. 35-36.

43 Rejestr spraw rozpatrywanych przez Komisję Skarbową Poznańską, APPoz., KSP, 3, k. 1-33.

44 Laudum sejmiku województw poznańskiego i kaliskiego, Środa 26 I 1650, BC, 1774, s. 227-228.

45 S. Oświęcim, Diariusz Stanistawa Oświęcima 1643-1651, [w:] Scriptores Rerum Polonicarum, t. 19, wyd. W. Czermak, Kraków 1907, s. 293; Protestacja Jana Kaweckiego, 3 XII 1650, APPoz., Gr. Pozn., 695, k. 930v-931.

46 Zob. Laudum średzkie, Środa 26 I 1650, BC, 1774, s. 228.

47 List przypowiedni dla Jacka Rozdrażewskiego, Warszawa 28 XII 1650, APPoz., Księgi grodzkie pyzdrskie, sygn. 85, k. 144. 
Andrzej Grudziński, objął dowództwo nad pułkiem złożonym z piechoty o takiej samej liczebności ${ }^{48}$. Tymczasem armia koronna miała coraz większe problemy z regularnym wypłacaniem żołdu, a i sami mieszkańcy bardzo niechętnie odnosili się do wojsk zarówno państwowych, jak i własnych samorządowych.

Problemy te nie ominęły wspomnianych zgrupowań. Porucznik Taubenheim z pułku Rozdrażewskiego skarżył się na przeora Kościelnej Wsi, że ten nie daje mu należnych kontyngentów wynikających $\mathrm{z}$ asygnacji, a nawet podburza chłopów do atakowania żołnierzy. Z kolei sam duchowny skarżył się, że to porucznik siłą wybiera stacje bez zezwolenia ${ }^{49}$. Podobna sytuacja miała miejsce w Babimoście, gdzie starosta Krzysztof Żegocki odmówił prowiantowania regimentów piechoty Grudzińskiego ${ }^{50}$.Wszystkie wojska cudzoziemskie miały znaleźć się docelowo pod komendą koniuszego litewskiego i generała gwardii królewskiej Bogusława Radziwiłła, a następnie wziąć udział w bitwie beresteckiej ${ }^{51}$. Niedługo po samej batalii Rozdrażewski zmarł w Lubartowie na zarazę, a komendę nad jego pułkiem oddano Wilhelmowi Butlerowi, cudzoziemcowi, którego rodzina otrzymała polski indygenat ${ }^{52}$. Zdarzenie to w znaczący sposób wpłynęło na postawę sejmiku wobec czynnika obcego w armii polskiej. Taka decyzja podjęta bez jego akceptacji musiała się liczyć z pewnymi konsekwencjami. Co prawda

48 List przypowiedni dla Andrzeja Grudzińskiego, Warszawa 18 XII 1650, APPoz., Gr. Pozn., 695, k. 1010-1010v.

49 Protestacja konwentu Kościelnej Wsi, Reprotestacja Jana Taubenheima, APPoz., Gr. Kal., 276, k. 108-108v.

50 Manifestacja Jana Przybylskiego, Protestacja Jana Przybylskiego, APPoz., Gr. Pozn., 696, k. 197v-198v.

51 B. Radziwiłł, Autobiografia, oprac. T. Wasilewski, Warszawa 1979, s. 174; Podziat wojska na putki z 14 VI 1651 przed batalia berestecka z wtaczeniem doń jednostek zaciagu cudzoziemskiego, [w:] Relacje wojenne..., s. 347; S. Oświęcim, Diariusz..., s. 293; J. Wimmer, Wojsko polskie..., s. 75-76.

521651 g. awgusta 10-17. - Diewnik wojennych destwijmeżdu polsko-szlachecki armii i ukrainskimi powstańcami posle bitwy pod Beresteczkom,[w:] Dokumenty oboswoboditelnoiwojneukrainskogonaroda 1648-1654, red. P.P. Gudzenko, A.K. Kasimenko, S.D. Piłkewicz, Kijew 1965, s. 604; J. Wimmer, Materiaty do zagadnienia organizacji i liczebności armii koronnej w latach 1648-1655, SMHW 1960, t. 5, s. 506-507; W. Czapliński, Butler Gottard Wilhelm, [w:] PSB 1937, t. 3, s. 150-151. 
zgrupowanie to przestało już być samorządowe, ale było to wciąż zgrupowanie stworzone według zapisów laudum średzkiego. Poza tym województwa wielkopolskie i tak musiały je utrzymywać.

Na zgromadzeniu w grudniu 1651 roku szlachta dyskutowała na ten temat i wyrażała swoje niezadowolenie z faktu, że musi płacić na tak duży oddział wojska, którym dowodzi obecnie człowiek, niezwiązany w żaden sposób z Wielkopolską. W efekcie całej sytuacji sejmik nie wyraził zgody dla kapitana Nataniela Lipki na suplementowanie pułku w województwach wielkopolskich, czego domagał się wspomniany oficer ${ }^{53}$. Co więcej, $\mathrm{w}$ instrukcjach sejmikowych na sejm 1652 roku domagano się bacznego przyjrzenia się wojskom cudzoziemskim służącym Rzeczypospolitej, ponieważ, jak sądzono, to w nich dochodziło do największych nadużyć i defraudacji ${ }^{54}$.

Możemy zatem zauważyć, że w momencie pewnego gestu samowoli ze strony władzy królewskiej rozgorzał spór, który pogłębiały dodatkowo problemy z finansowaniem, a mianowicie niemożność zapłacenia żołdu (nadmiernie wysokiego w przypadku wojsk cudzoziemskich, jak uważała szlachta) oraz inne sprawy, jak brak należytej dyscypliny, grabieże oraz dowództwo nad wielkopolskim wojskiem przez nieznane osoby. Niestety, postulaty szlachty nie doczekały się realizacji ze względu na zerwanie sejmu w 1652 roku przez posła upickiego Władysława Sicińskiego ${ }^{55}$. Sytuacja wojenna spowodowała, że sejmik zmuszony był w 1652 roku po raz kolejny zaciągnąć wojska powiatowe. W jego skład wszedł dość potężny, bo liczący 1000 porcji, pułk piechoty cudzoziemskiej pod dowództwem Łukasza Górskiego ${ }^{56}$. Na kolejnej sesji sejmiku powiększono wojska powiatowe o rajtarów i arkebuzerów ${ }^{57}$. Zgrupowania te natychmiast przeszły do

53 Laudum sejmiku województw poznańskiego i kaliskiego, Środa 15 XII 1651, BC, 1774, s. 243-248.

54 Instrukcja sejmikowa, Środa 15 XII 1651, APPoz., Gr. Pozn., 697, k. 4-12.

55 VC, t. 4, vol. 1, s. 251.

56 Laudum sejmiku województw poznańskiego i kaliskiego, Środa 11 VI 1652, BC, 1774 , s. 251-254.

57 Laudum sejmiku województw poznańskiego i kaliskiego, Środa 8 VII 1652, BC, 1774, s. $255-257$. 
komputu państwowego ${ }^{58}$. W przeciwieństwie do pułku Rozdrażewskiego oficerami w pułku Górskiego byli głównie Wielkopolanie poza Niemcem Melchiorem Krausem ${ }^{59}$.

Tymczasem problem zapłaty wojsku stawał się coraz bardziej dotkliwy i to nie tylko w stosunku do cudzoziemców, ale i całej armii. Dotknął zarówno pułk Górskiego, jak i inne choragwie powiatowe, w tym jazdę Krzysztofa Żegockiego. W tym samym czasie poważne problemy przeżywał niedawny pułk Jacka Rozdrażewskiego. Otóż sekretarz z pułku, Jerzy Gaebel, skarżył się na Andrzeja Przyjemskiego, że ten specjalnie utrudnia mu uzyskanie pieniędzy na pułk, których suma wynosiła 64 tys. złp ${ }^{60}$. Sytuacja stawała się coraz trudniejsza. Żołnierze, nie mogąc doczekać się należnych pieniędzy, na własną rękę dokonywali ich poboru, co powodowało ostry sprzeciw miejscowej ludności. O miejsca stacjonowania i suplementowania wojska toczyły się gwałtowne spory między samymi żołnierzami. Konflikt między kwatermistrzem z pułku Górskiego Mikołajem Polewiczem a podpułkownikiem Jerzym Klejną o aprowizacje w Wałczu o mało nie skończył się rozlewem krwi pomiędzy żołnierzami walczącym de facto po tej samej stronie ${ }^{61}$. Pomimo rozkazów z sejmiku o jak najszybsze wyjście na Ukrainę $e^{62}$ licznych, ponaglających apeli królewskich ${ }^{63}$ i hetmańskich wojska zbierały się niezwykle opieszale. Gdy w końcu udało im się wyjść z prowincji, niedługo po wymarszu zmarł sędziwy Łukasz Górski. Król po raz kolejny bez konsultacji z sejmikiem powołał cudzoziemca Diega Villa

58 T. Ciesielski, M. Nagielski, Komputy wojska koronnego w latach 1651-1653, SMHW 2003, t. 40, s. 254-255.

59 Przysięga pułkownika Łukasza Górskiego i jego pułku, Kalisz 26 VIII 1652, Protestacja kolegium kaliskiego, APPoz., Gr. Kal., 277, k. 471v, 490-490v; Protestacja Andrzeja Koffmańskiego, Protestacja kapituły poznańskiej, APPoz., Gr. Pozn., 697, k. 493-495, 507; Protestacja Sebastiana Lajszczewskiego, APPoz., Gr. Kal., 278, k. 28-29.

60 Protestacja Jerzego Gaebela, Plenipotencja dla Jerzego Gaebela, APPoz., Gr. Pozn., 697, k. 452-454v, 583v-584.

61 Protestacja Mikołaja Polewicza, APPoz., Gr. Pozn., 697, k. 503v-505v.

62 Laudum sejmiku województw poznańskiego i kaliskiego, Środa 9 IX 1652, BC, 1774, s. 260-263.

63 Uniwersał JKM do oficerów wojsk kozackich, arkebuzerskich i dragońskich, Warszawa 3 VIII 1652, APPoz., Gr. Pozn., 697, k. 502v-503, Uniwersał JKM do żołnierzy, 6 XII 1652, APPoz., Gr. Kal., 277, k. 685-685v. 
Logosa na pułkownika piechoty Górskiego ${ }^{64}$. Ten akt rozwścieczył szlachtę poznańską i kaliską. Na sejmiku średzkim 8 marca 1653 roku odczytywano list prymasa Andrzeja Leszczyńskiego, którego jedna z części poświęcona była właśnie wojskom cudzoziemskim. Ostro atakował on oficerów autoramentu cudzoziemskiego, zarzucając im pazerność oraz celowe opóźnianie formowania i uzupełniania oddziałów, a nawet fałszerstwa rejestrów popisowych ${ }^{65}$. Przebieg obrad był pod wyraźnym wpływem listu prymasa. Oprócz natychmiastowego wyjaśnienia spraw związanych z zapłatą wojsku i nadużyciami oraz ukarania winnych posłowie wielkopolscy mieli domagać się natychmiastowego usunięcia Villa Logosa z funkcji pułkownika i oddania komendy nad pułkiem synowi Łukasza Górskiego - Stanisławowi ${ }^{66}$. Sejm brzeski próbował załatwić sprawy związane z zapłatą w wojsku oraz dyscypliną żołnierską i walką z nadużyciami, ale kwestię pułku Górskiego pominięto ${ }^{67}$. Możliwe, że brak zdecydowania króla w tej materii doprowadził do całkowitego zignorowania przez województwa poznańskie i kaliskie wyprawy łanowej w 1653 roku $^{68}$. Ponadto król żalił się, że podatki uchwalone przez wspomniane województwa nie wpływają w należytej wysokości. Konflikt pomiędzy królem a szlachtą wielkopolską stał się faktem.

Oficjalne stanowisko szlachta średzka wystosowała na sejmiku z 31 grudnia 1653 roku. Tym razem instrukcje sejmikowe zawierały konkretne postulaty co do funkcjonowania całego wojska cudzoziemskiego utrzymywanego przez państwo. Posłowie mieli protestować przeciwko żołnierzom zagranicznym, na których potrzeba nie tylko ogromnego żołdu, ale również ich funkcjonowanie jest niezwykle uciążliwe. Zgodę można było wyrazić ewentualnie na 3 tys. wojska i to przy spełnieniu warunku

${ }^{64}$ M. Wagner, Stownik biograficzny oficerów polskich drugiej potowy XVII wieku, t. 1, Oświęcim 2013, s. 280.

${ }^{65}$ List prymasa Andrzeja Leszczyńskiego do sejmiku średzkiego, Toruń 4 III 1653, Biblioteka Uniwersytetu Wrocławskiego, akc. 1949/440, k. 550-552; T. Ciesielski, Sejm brzeski 1653 r., Toruń 2004, s. 89-91.

66 Instrukcja sejmikowa, Środa 8 III 1653 r., APPoz., Gr. Pozn., 698, k. 359-363; T. Ciesielski, Sejm brzeski..., s. 92.

67 T. Ciesielski, Sejm brzeski..., s. 141-144, 162-163, 198-201.

68 Idem, Wyprawa tanowa 1653 r., „Zeszyty Naukowe Wyższej Szkoły Pedagogicznej im. Powstańców Śląskich w Opolu” 1994, t. 30, s. 66. 
polskiego pochodzenia oficera, bo cudzoziemscy zbyt dużo liczyli sobie za swoje usługi. Poza tym król miał nie tworzyć regimentów przekraczających 500 żołnierzy. Miano również postawić na polską piechotę. Mowa była także o szkodach, jakich doznały województwa od oficerów cudzoziemskich, którzy nie bacząc na przysięgi, wybierali dodatkowe pieniądze i towary. Posłowie mieli wspomnieć o tym, że po bitwie pod Batohem, kiedy to ponieśli ogromne wydatki związane z utrzymywaniem wojska powiatowego i komputowego, w tym dużych regimentów cudzoziemskich, odmówili partycypacji w wyprawie łanowej ze względu na poniesione koszty ${ }^{69}$. $\mathrm{Na}$ kolejnym sejmiku 19 maja 1654 roku rozpatrzono po raz kolejny sprawy związane $\mathrm{z}$ wojskiem cudzoziemskim. Instrukcje sejmikowe na nim sporządzone ponawiały postulaty dotyczące pułku Villa Logosa, a także oznajmiały, że nie będzie zgody na dalsze utrzymywanie państwowego regimentu pułkownika Molla w ramach komputów wojewódzkich. Sprawa pułku Górskiego miała zostać rozstrzygnięta na najbliższym sejmie, w przeciwnym razie województwo poznańskie i kaliskie nie będzie utrzymywało żadnych cudzoziemskich regimentów ${ }^{70}$. Faktycznie, pod wpływem nacisków król zdecydował się odprawić Villa Logosa, a pułk Łukasza Górskiego przekazać w zarząd generałowi artylerii Krzysztofowi Grodzickiemu, uspokajając choć trochę sytuację $^{71}$. Nie zmieniło to natomiast innych decyzji królewskich i nadal utrzymywano w ramach repartycji wojewódzkich pułk Butlera oraz inne cudzoziemskie ${ }^{72}$.

Spór z okresu powstania Chmielnickiego zdaje się rzutować w pewien sposób na sytuację w dalszych latach. Analizując lauda sejmikowe,

69 Laudum sejmiku województw poznańskiego i kaliskiego, Środa 31 XII 1653, BC, 1774, s. 269-272; Instrukcja sejmikowa, Środa 31 XII 1653, APPoz., Gr. Pozn., 699, k. $15-20 v$.

70 Laudum sejmiku województw poznańskiego i kaliskiego, Środa 19 V 1654, BC, 1774, s. 275, 277-278; Instrukcja sejmikowa, Środa 19 V 1654, APPoz., Gr. Pozn., 699, k. 278-282.

71 B. Staręgowski, „Ciklop” z Kodaka. Zizn i wojenna jadej atetnost Kszisztofa Grodzickogo, generalakoronnoi artylerii, „Frontiri Mista” 2016, t. 5, s. 34-36.

${ }^{72}$ Asygnacja dla Wilhelma Butlera, 20 XII 1653, Uniwersał JKM do szlachty województw poznańskiego i kaliskiego, Warszawa 25 IV 1654, APPoz., Gr. Pozn., 699, k. 68, 274, 277-277v. 
możemy zauważyć, że praktycznie zaniechano powoływania wojska powiatowego, walcząc głównie przy użyciu żołnierzy łanowych i pospolitego ruszenia ${ }^{73}$. W laudum poprzedzającym wydarzenia określane mianem kapitulacji pod Ujściem planowano powołać trzy regimenty piechoty cudzoziemskiej w sile 3 tys. żołnierzy, a przynajmniej taki zamiar znajdował się w laudum z kwietnia 1655 roku. Niestety, nie zawierało ono żadnych szczegółów odnośnie do zorganizowaniatych formacji, a jedynie lakoniczne wzmianki o nadzorze starosty generalnego i obu wojewodów oraz standardowego żołdu, jaki był wówczas przewidziany dla piechoty. Istotną cechą tego zaciągu miało być odbywanie się werbunku na terytorium należącym do zaprzyjaźnionego księcia ${ }^{74}$. Chodziło oczywiście o terytorium marchii brandenburskiej, gdzie rządy sprawował elektor Fryderyk Wilhelm. Nawet król nie oponował przed takim rozwiązaniem, życzył sobie jedynie zatwierdzenia oficerów poprzez listy przypowiednie ${ }^{75}$. Ostatecznie zaniechano powołania tych wojsk, z uwagi na zaporowe warunki samego elektora, który zażądał, by piechota werbowana na terytorium marchii weszła w skład załóg miast. Sprawę definitywnie zamknęło pojmanie na terytorium Wielkopolski w połowie kwietnia Jakuba Holsta, którego oskarżono o szpiegostwo na rzecz elektora brandenburskiego. Gromadził on informacje o stanie twierdz, przepraw rzecznych, słabych punktach w systemie obronnym oraz siłach wielkopolskich ${ }^{76}$. Sprawa wywołała

73 Laudum sejmiku województw poznańskiego i kaliskiego, Środa 10 V 1666, BC, 1774, s. 351-353; L. Kubala, Wojna szwedzka w roku 1655 i 1656, Lwów-Warszawa-Poznań 1917, s. 70-73, 150-151, 269-270, 320-324; J. Dworzaczkowa, Sprawy wojska..., s. 61-63; J. Wisłocki, Walka z najazdem szwedzkim w Wielkopolsce 1655-1656, „Studia i Materiały do Dziejów Wielkopolski i Pomorza” 1956, t. 2, z. 2, s. 53-74.

74 Laudum sejmiku województw poznańskiego i kaliskiego, Środa 28 IV 1655, BC, 1774, s. 288-289; B. Szymczak, Stosunki Rzeczypospolitej z Brandenburgia i Prusami Książęcymi w latach 1648-1658 w opinii i dziataniach szlachty koronnej, Warszawa 2002, s. 119.

75 VC, t. 4, vol. 1, s. 351; B. Szymczak, Stosunki Rzeczypospolitej z Brandenburgia..., s. 127. Według B. Szymczak król wyrażał zgodę na taki zaciąg, traktując go jedynie jako standardową procedurę werbunku obcego żołnierza na służbę Rzeczypospolitej, a nie zagrywkę polityczną elektora, związaną z poszerzaniem jego wpływów w Wielkopolsce.

76 A. Kamieński, Kulisy kapitulacji wielkopolskiego pospolitego ruszenia pod Ujściem w 1655 roku, „Klio. Czasopismo Poświęcone Dziejom Polski i Powszechnym” 2017, 
powszechne oburzenie i protest samych mieszkańców, którzy nie chcieli "gościć" u siebie wojska z obcego państwa ${ }^{77}$. Można tu upatrywać niechęć do tego typu formacji właśnie z tego powodu, ale również obawę przed wysłaniem wojsk na Ukrainę, co w tym okresie król czynił dość chętnie ${ }^{78}$, nie zważając na konieczność posiadania odpowiedniej siły zbrojnej, potrzebnej do odparcia agresji szwedzkiej.

W 1667 roku planowano również powołać żołnierza powiatowego na wojnę z Turcją. Jednakże brakowało wśród tych zgrupowań jakichkolwiek formacji cudzoziemskich, a ostatecznie i to laudum nie doczekało się realizacji $^{79}$. W późniejszych latach również powoływano wojska powiatowe, jednak sejmik zaciągał wówczas jazdę pancerną, a więc formację będącą częścią autoramentu narodowego ${ }^{80}$.

Niechęć do żołnierzy cudzoziemskich, ale również do wojska jako całości rosła, na co niewątpliwie miały wpływ wydarzenia mające miejsce na terenie obu województw. Walka z najazdem szwedzkim, konfederacje wojskowe czy rokosz Jerzego Lubomirskiego pogłębiały te problemy. Sytuację zaogniały zarówno rekwizycje, jak i grabieże dokonywane przez wojska cudzoziemskie, będące na służbie państwowej, których utrzymanie spadało na województwa wielkopolskie ${ }^{81}$ czy regimenty posiłkowe, wysłane przez cesarza i króla węgierskiego Karola Habsburga przeciwko Szwedom ${ }^{82}$. Problematyczne było zapewnienie utrzymania tych wojsk, co przecież spadałona województwa poznańskie i kaliskie, które zmuszone były je utrzymywać i dostarczać prowiant ${ }^{83} \mathrm{w}$ momencie, gdy tereny

t. 43, z. 4, s. 54, 56; B. Szymczak, Stosunki Rzeczypospolitej z Brandenburgia..., s. 135-137 .

77 A. Sajkowski, Krzysztof Opaliński. Wojewoda poznański, Poznań 1960, s. 220-221.

78 Uniwersał JKM do żołnierzy, Warszawa 7 VI 1655, APPoz., Gr. Kal., 279, k. $1022 \mathrm{v}-1023$.

79 Laudum sejmiku województw poznańskiego i kaliskiego, Środa 7 II 1667, BC, 1774, s. 361-363.

80 Z. Hundert, Powiatowe choragwie kozackie..., s. 63-94.

81 Instrukcja sejmikowa, Środa 7 II 1667, APPoz., Gr. Kal., 282, k. 385-402.

82 Manifestacja Teresy Leśniewskiej, Protestacja Stanisława Strzeleckiego, APPoz. Księgi grodzkie kcyńskie, sygn. 87, s. 608-609, 628-631.

83 Respons dany Janowi Gnińskiemu i Stanisławowi Jaraczewskiemu dla JKM, III 1658, APPoz. Księgi grodzkie kcyńskie, sygn. 87, s. 423-425. 
te przeżyły istną gehennę okupacji szwedzkiej. W każdym z wymienionych wyżej przypadków sejmik próbował zabezpieczyć mieszkańców, przydzielając komisarzy, nakładając kary na swawolników czy nakazując urzędnikom formowanie obrony domowej. Nie rozwiązywało to jednak problemów. Nasilenie oporu przeciwko królowi i jego decyzjom, związanym z zaciąganiem cudzoziemców, przejawiało się choćby w postulatach żołnierzy związkowych, którzy domagali się wypłat zaległych pieniędzy. W przeciwnym razie dokonywali siłowych rekwizycji potrzebnych dóbr ${ }^{84}$. Niezbędne okazało się w końcu wskazanie przyczyn takiego stanu rzeczy, toteż wśród postulatów szlacheckich najbardziej chwytne były te mówiące o zaprzestaniu procederu zbytniego rozdawnictwa indygenatów oraz nobilitacji zagranicznych oficerów ${ }^{85}$, co w konsekwencji miało doprowadzić do ograniczenia w wojsku czynnika obcego.

\section{Wnioski}

Podsumowując, sprawa służby żołnierzy i oficerów cudzoziemskiego zaciągu była kwestią niezwykle skomplikowaną w swojej naturze. Sejmik średzki dość niechętnie wypłacał pieniądze na wojsko, a tym bardziej robił to zagranicznym oficerom i żołnierzom. Początkowo formacje tego typu funkcjonowały bez większych problemów. Pojawiły się one w momencie zmiany dowództwa na oficerów cudzoziemskich nieakceptowanych przez sejmik oraz problemów z zapłatą wojsku. Cudzoziemców zaczęto oskarżać o zbytnie nadużycia, pazerność, fałszowanie kwitów poborowych oraz nadmierne koszty funkcjonowania. Jak wskazuje Jolanta Dworzaczkowa, oficerowie cudzoziemscy w bardzo skrupulatny sposób byli kontrolowani i ostro piętnowani za wszystkie nadużycia, jeśli takowe wystąpiły, znacznie bardziej niż Polacy dokonujący takich samych czynów ${ }^{86}$. Trudno nie zgodzić się z tym stanowiskiem. Patrząc przez pryzmat wszystkich formacji i jednostek

84 Rejestr szkód w miasteczku Jarocinie przez wojska przez niego przechodzące, 17 VIII 1665, APPoz., Gr. Kal., 286, k. 360-363v.

85 Protestacja posłów z sejmiku średzkiego wystosowana do JKM, APPoz., Gr. Kal., 285, k. 17-18.

86 J. Dworzaczkowa, Sprawy wojska..., s. 64. 


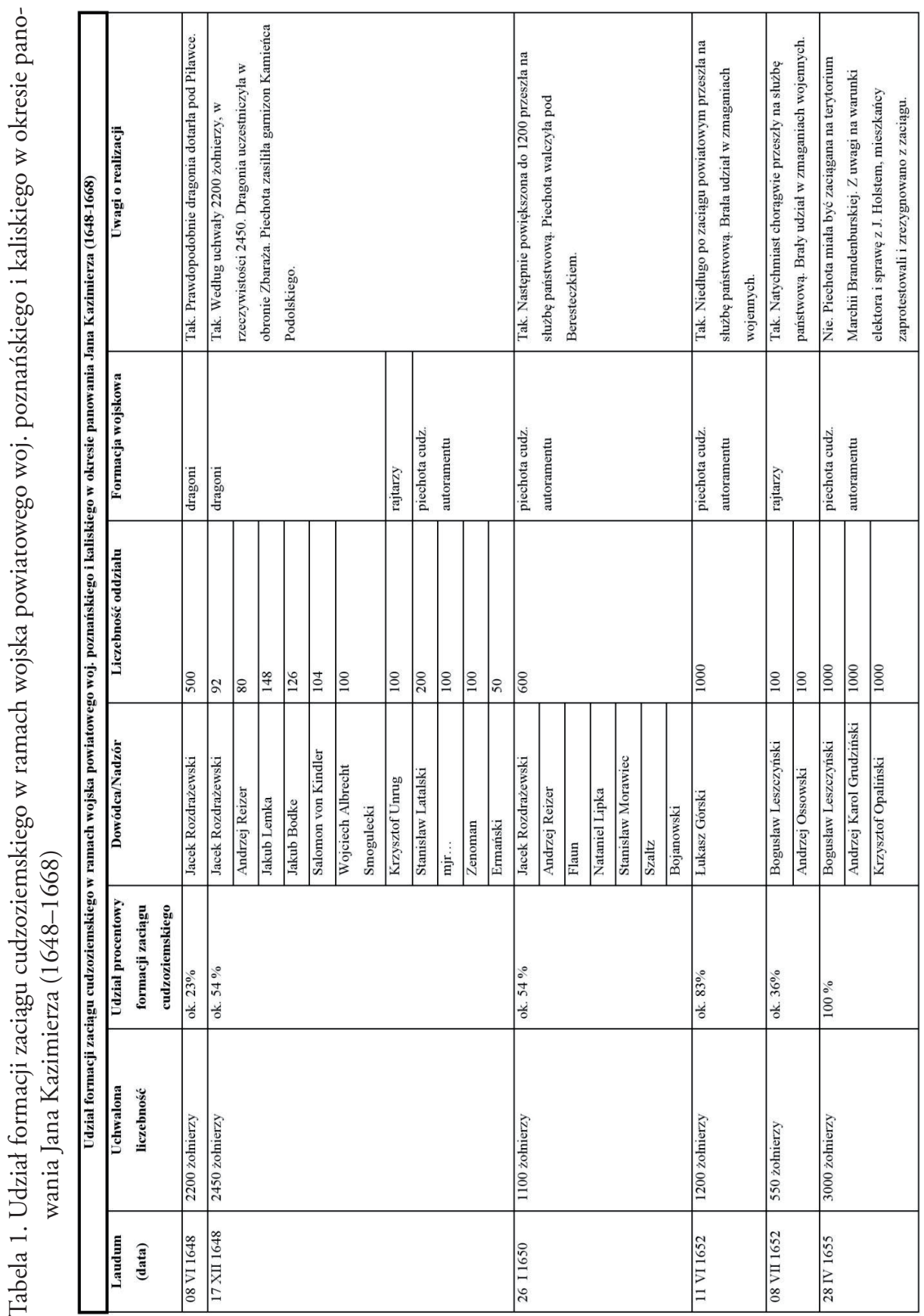


wojskowych, które przewinęły się przez wielkopolskie wojsko powiatowe, można zauważyć, że oficerowie cudzoziemscy w pewnym momencie stali się niejako kozłem ofiarnym, który ponosił karę za niewydolny system podatkowy państwa. Postępowanie żołnierzy cudzoziemskich nie odbiegało zbytnio od tego, którego dokonywały rodzime wojska. Jedynym niezaprzeczalnym faktem jest, że formacje te były droższe, ale nie na tyle, by przekraczać koszty powoływania husarii czy arkebuzerów, których sejmik zaciągał bardzo chętnie. Zresztą patrząc na dane przedstawione w tabeli (tab. 1), można zauważyć, że wojska zaciągu cudzoziemskiego, mimo narzekań na nie ze strony szlachty wielkopolskiej, stanowiły poważną część składu osobowego w większości zaciągów powiatowych w omawianym okresie, kilkukrotnie przekraczając 50\%. Na koniec warto zauważyć, że nieufne podejście do wojska o charakterze cudzoziemskim było specyficzne dla wszystkich sejmików, które już od czasów bardzo dawnych niechętnie odnosiły się do finansowania przedsięwzięć wojskowych. Szczególnie uwidaczniało się to na sejmikach oddalonych od głównego teatru działań wojennych. Wszystkie czynniki wymienione uprzednio wpłynęły na to, że sejmik po okresie wojen kozackich zaprzestał powoływania wojsk autoramentu cudzoziemskiego w charakterze wojsk powiatowych. 